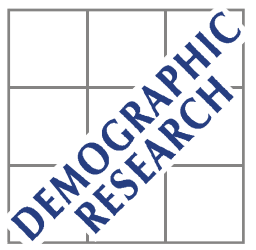

Demographic Research a free, expedited, online journal of peer-reviewed research and commentary in the population sciences published by the Max Planck Institute for Demographic Research Konrad-Zuse Str. 1, D-18057 Rostock · GERMANY www.demographic-research.org

DEMOGRAPHIC RESEARCH

SPECIAL COLLECTION 2, ARTICLE 14

PUBLISHED 16 APRIL 2004, PAGES 355-386

www.demographic-research.org/special/2/14/

DOI: 10.4054/DemRes.2004.S2.14

Research Article

\title{
Urbanization, development, and under-five mortality differentials by place of residence in São Paulo, Brazil, 1970-1991
}

\section{Narayan Sastry}

The papers in this special collection were presented at the seminar "Determinants of Diverging Trends in Mortality", held at MPIDR, Rostock on 19-21 of June, 2002. The seminar was organized by the Max Planck Institute for Demographic Research and the Committee on Emerging Health Threats of the International Union for the Scientific Study of Population.

(C) 2004 Max-Planck-Gesellschaft. 


\section{Table of Contents}

1 Introduction 356

2 Background $\quad 357$

3 Data and methods $\quad 359$

4 Results 362

5 Conclusions 368

6 Acknowledgements $\quad 369$

$\begin{array}{ll}\text { Notes } & 370\end{array}$

References 372

Tables \& Figures 378 
Research Article

\title{
Urbanization, development, and under-five mortality differentials by place of residence in São Paulo, Brazil, 1970-1991
}

\author{
Narayan Sastry ${ }^{1}$
}

\begin{abstract}
In this paper, I examine differentials in under-five mortality by place of residence for the state of São Paulo, Brazil. I examine differentials between urban and rural areas, and by location within urban areas, over a 21-year period between 1970 and 1991. I also investigate economic inequalities in under-five mortality for urban areas. For São Paulo, much of the entire infant and child mortality transition unfolded during the period 1970-1991. I investigate whether these improvements in mortality were accompanied by narrowing differentials by place of residence and declining economic inequalities in mortality. I draw on microdata from Brazilian censuses conducted in 1970, 1980, and 1991.
\end{abstract}

RAND Corporation, 1700 Main Street, P.O. Box 2138, Santa Monica, CA 90407-2138. Email:

sastry@rand.org 


\section{Introduction}

There have been dramatic improvements in health and mortality for most of the less developed world during the past several decades, especially for infants and children (Note 1). Cross-sectional studies have highlighted important differentials in infant and child mortality according to social, economic, and demographic factors, with ruralurban differentials among the most commonly examined. Previous studies that have focused on rural-urban mortality differentials for infants or children include Adetunji (1994), Brockerhoff (1990, 1994, and 1995), Defo (1996), and Sastry (1997). Until recently, most studies of intra-urban mortality differentials considered differences across groups defined according to social or economic characteristics (e.g., Timaeus and Lush, 1995). However, there are a growing number of analyses of spatial variation in infant and child mortality that have been conducted-especially for Brazil (Note 2). Despite this attention, there is an important research gap in documenting and explaining trends in rural-urban or intra-urban differentials in infant and child mortality in less developed countries. Although there are studies that have described these trends (e.g., Carvalho and Wood, 1978; Sawyer, Fernández-Castilla, and Monte-Mor, 1987; Wood and Carvalho, 1988), there are few that have sought to explain them. Thus, little is known about both how and why rural-urban or intra-urban differentials have changed over a period in which the development processes unfolded and levels of urbanization rose, women's educational attainment improved, infrastructure spread, and income and wealth increased. For example, in a review of Brazilian studies on urbanization and health, Akerman et al. (1994) concluded that there were major gaps in understanding the relationship between urbanization and health in Brazil, which is similar to the situation in other developing countries (Harpham and Tanner, 1995).

In this paper, I examine differentials in under-five mortality by place of residence for the state of São Paulo, Brazil. I examine differentials between urban and rural areas, and by location within urban areas, over a 21-year period between 1970 and 1991 . I also investigate economic inequalities in under-five mortality for urban areas. For São Paulo, much of the entire infant and child mortality transition unfolded during the period 1970-1991. I investigate whether these improvements in mortality were accompanied by narrowing differentials by place of residence and declining economic inequalities in mortality. Alternatively, did the most advantaged areas and people benefit to a greater extent? The focus on urbanization is important because it has been one of the dominant underlying demographic processes during this period, not only in São Paulo, but also in the rest of Brazil, Latin America, and the developing world. I draw on microdata from Brazilian censuses conducted in 1970, 1980, and 1991. The availability of detailed individual- and household-level measures and extremely large sample sizes are the major strengths of these data; few other cities or regions in less 
developed countries have data of the quality, depth, and detail that are available for São Paulo.

I begin, in the next section, by providing some background on trends and differentials in infant and child mortality in São Paulo, Brazil, over the past 30 to 40 years. In Section 3, I describe the data and methods. The results are presented in Section 4, and I end the paper with some conclusions.

\section{Background}

São Paulo is the largest state in Brazil, and the metropolitan region of São Paulo is the most industrialized city in Latin America. The state's 1991 population of 31.5 million was more than 20 percent of the country's total (Fundação SEADE, 1993). This region forms Brazil's urban-industrial heartland and dominates the country economically. For example, metropolitan São Paulo contains one-tenth of Brazil's population but generates one-third of its income (Abranches, 1995).

The city and state lead Brazil and Latin America in many demographic and socioeconomic trends. Since 1970, the state has continued to experience declining fertility, rapid urbanization, and increases in levels of income. For example, over this period, the total fertility rate dropped from 5.0 to under 2.5 (Martine, 1996). By the mid-1990s, 93 percent of the state's population lived in urban areas, up from an already high 80 percent in 1970. Figure 1 shows the growing concentration of the population in urban areas between 1970 and 1991, which was centered on the metropolitan São Paulo region in the southeast part of the state where almost half of the state's population lives.

Like many other major cities in the developing world, during the past several decades metro São Paulo experienced rapid population growth with little attention paid to environmental degradation (Goldani, 1983). Population growth, particularly in the periphery of metropolitan São Paulo, exceeded the growth rate in the availability of drinking water, sewage disposal systems, and preventive and curative health services (Merrick and Graham, 1979). By the mid-1980s, rapid population growth in the state posed serious air, water, and solid and hazardous waste problems that are known to have had significant deleterious effects on health (Thomas, 1987).

\section{Mortality decline in São Paulo}

Infant and child survival in São Paulo state has improved dramatically since the early 1970s, with the infant mortality rate, based on vital registration data, declining from 84 per 1,000 in 1970 to less than 20 per 1,000 today (see Figure 2). Figure 3 shows the spatial pattern of the decline in infant mortality since 1970. The largest declines were 
in metro São Paulo and its periphery, as well as in relatively sparsely populated rural areas in the western parts of the state. The large decline in metro São Paulo reflects high infant mortality rates in this area in 1970 and, to a lesser extent, in 1980; by 1991, rates had declined greatly throughout most of the state, although high infant mortality rates persisted in rural areas in the south and east.

The rapid improvement in infant and child mortality in São Paulo beginning in the early 1970s followed a decade-long period during which the health transition was stalled in Brazil. In fact, as Figure 2 shows, between 1964 and 1973, infant mortality rates in São Paulo city actually increased by 30 percent, from 69 per 1,000 to 94 per 1,000 (Monteiro and Benicio, 1989). The rise in infant mortality in São Paulo during these years has been studied extensively. The 1964-1973 period corresponds to the main years of the Brazilian economic miracle, during which the economy expanded at a rate of more than 10 percent a year. The "miracle years" began with a military takeover, after which the government moved sharply toward promoting rapid industrialization (Evans, 1978). The period was characterized by a major decline in real wages: The legal minimum wage declined roughly 60 percent in real terms between 1964 and 1973. Several analysts (e.g., Wood, 1982; Yunes, 1981; Sawyer, 1981) have suggested that the economic policies of the military government were the main cause of the upturn in infant mortality during this period in São Paulo. However, there were other concurrent changes that may have had important effects on population health. Monteiro and Benicio (1989) noted that during the 1964-1973 period the coverage of the water supply system deteriorated and the coverage of the sewage system declined. Leser (1974) found that health services stagnated from 1970 to 1974, especially in urban areas experiencing high rates of population growth. The negative effects of declining expenditures on health services were perhaps exacerbated by a growing emphasis on the quantity of services delivered rather than quality, efficacy, or equity (Macedo, 1984). Some studies of this period found that infant mortality rates were higher in urban areas than in rural areas, the opposite of the pattern found elsewhere in Latin America (Puffer and Serrano, 1973; Behm et al., 1976).

There was a rapid decline in the infant mortality rate beginning in the mid 1970s: Between 1973 and 1983, the infant mortality rate in São Paulo city fell by 56 percent, from 94.0 per 1,000 to 41.6 per 1,000 (Monteiro et al., 1989). The restrictive wage policies imposed by the military government were relaxed at this time and the legal minimum salary was stabilized between 1973 and 1982 (Monteiro and Benicio, 1989). Most analysts have argued, however, that declining infant mortality rates during the 1970s were largely due to infrastructure improvements (Costa and Duarte, 1989; Zúñiga and Monteiro, 1995). During the early 1970s, Brazil embarked on an intensive effort to improve water supply and sanitation, two important urban environmental conditions with a known link to mortality (Merrick, 1985). The national water and sanitation plan, 
known as PLANASA, raised the proportion of households in São Paulo with running water from 71.3 percent in 1973 to 98.6 percent in 1984 (Sawyer, Fernández-Castilla, and Monte-Mor, 1987). Consistent with the explanation that improvements in infrastructure brought about the reduction in infant and child mortality, Monteiro et al. (1989) note that the most marked decline occurred in deaths due to diarrheal diseases, which fell from 23.2 per 1,000 to 4.3 per 1,000 between 1973 and 1983. Other important changes that probably improved infant and child health were increases in breastfeeding durations, the use of oral rehydration therapy, immunization rates, and the number of health centers (Monteiro et al., 1989; Victora et al., 1996). It appears that immunization rates may have increased to as much as 90 percent from only 50 percent a decade earlier. The number of health clinics doubled between 1974 and 1984, while the number of doctors per clinic tripled (Monteiro and Benicio, 1989).

The late 1970s marked the beginning of a new era of economic recession, with a major debt crisis in 1981-1982. Unemployment and inflation increased dramatically, and there were falling levels of expenditures on education and health. However, there is no evidence for Brazil that the 1981-1982 crisis had any effect on the pace of decline for infant and child mortality (Rios Neto and Moreira, 1994) or much effect on morbidity, schooling, immunization levels, and other measures of infant and child wellbeing (Monteiro et al., 1989; Paim and Costa, 1993). This situation is similar to the experience of many other developing countries that suffered through macroeconomic adjustment policies in the early 1980s (Behrman and Deolalikar, 1991; Palloni, Hill, and Aguirre, 1996; National Research Council, 1993). Finally, recent studies suggest that the public health programs introduced in the late 1980s and early 1990s may have made a large contribution to improvements in infant and child health in Brazil during the past decade (Simões and Oliveira, 1997).

In summary, there has been a major improvement in infant and child survival in São Paulo over the past three decades. Factors that are potentially important in explaining this improvement include economic growth, the development of basic infrastructure, modified demographic and reproductive behaviors, and changes in socioeconomic characteristics. Substantially less is known about how differentials and inequalities in under-five mortality unfolded over this period.

\section{Data and methods}

The data for this study come from the survey component for São Paulo of the Brazilian population censuses of 1970,1980, and 1991. The survey component of the census was administered to a 25-percent sample of households in 1970 and 1980; the 1991 census included a 10-percent sample for municipalities with a population of 15,000 or above 
and a 20-percent sample for the remainder. In all years, detailed information was obtained on housing conditions as well as demographic, social, and economic characteristics of each resident. By design, the specific measures were highly comparable over time. An important strength of these data is their exceptionally large sample sizes. Although I restricted the analysis to a subset of women in their childbearing years, the results are based on a total sample of more than 1.2 million women across the three datasets.

Each census included questions for adult women on the number of children they had borne and the number of these children surviving. Tabulations of the responses can be used to indirectly estimate levels of infant and child mortality, based on techniques developed by Brass et al. (1968) and refined by others (Sullivan, 1972; Trussell, 1975). I used these estimates together with individual responses to the questions to construct a child mortality index for each mother, following the methods of Trussell and Preston (1982). This index was then used to indirectly estimate levels of under-five mortality before and after controlling for a variety of individual-level demographic and socioeconomic characteristics through linear regression analysis.

The index accounts for the duration of children's exposure to the risk of death based on the mother's age, and assumes that the risk of death by child age is proportional to a standard mortality schedule, and, therefore, is proportional to the risk faced by other children (Trussell and Preston, 1982). The standard schedule is given by a model life table. The proportionality factor for each mother is the observed number of deaths divided by the expected number of deaths based on the standard mortality schedule. I estimated the proportionality factor separately for subgroups of women organized by five-year age categories and level of education (Note 3).

I included only women age 20-34 years in the analysis because mother's age was used to control for the duration of exposure to the risk of death; consequently, deaths among older women correspond to births occurring in the more distant past. Because the covariates reflect conditions at the time of the interview, the inclusion of older women - and, hence, children born in the more distant past—may have led to biased results. In addition, older women are more likely to make reporting errors such as understating the number of children born. I excluded women age 15-19 years because children of teenage mothers face higher mortality due, in part, to their mother's age (Note 4). The most important assumption behind these estimates is that fertility and childhood mortality levels have been constant in the recent past. Restricting the analysis to women age 20-34 years minimizes potential problems.

The expected number of dead children for the $j$ th woman in age group $d$ and education group $i, E_{i j}$, was given by

$$
E_{i j}=B_{i j} \times P D_{i}^{s}(d),
$$


where $B_{i j}$ is the number of children born to this woman and $P D_{i}^{s}(d)$ is the expected proportion of children who died among women in age group $d$ and education group $i$ under the standard mortality schedule. I estimated $P D_{i}^{s}(d)$ by inverting the conventional procedure for estimating childhood mortality based on summary information from mothers on the number of children ever born and children dead.

I calculated a value of the child mortality index $(C M I)$ for each woman in the sample. This index is the ratio of observed child deaths $\left(O_{i j}\right)$ to expected child deaths $\left(E_{i j}\right)$ for the $j$ th woman in the $i$ th education group:

$$
C M I_{i j}=O_{i j} / E_{i j}
$$

This index forms the outcome variable for the analysis of levels and inequality in child mortality. In presenting the results on the levels of child mortality, I converted the index to an estimated under-five mortality probability, $q(5)$, by multiplying the $q(5)$ value for the chosen standard life table by the weighted average of the child mortality index, with the number of live births to each woman serving as the weight (Note 5). I chose Coale-Demeny West regional model life table level 18.5 as the mortality standard for this study, based on a preliminary analysis of child mortality levels in São Paulo (results not shown) that used indirect estimation techniques described in Manual X (United Nations, 1983). Preston and Haines (1991) recommended using the $q(5)$ life table parameter because it is likely to be the least sensitive to time trends or an error in the choice of model life table. The weighting procedure provided a useful way to combine child mortality information across women of a wide age range (20-34 years) who had a corresponding large variation in the number of children born (and, hence, exposed to the risk of death). Values for the weighted average of $q(5)$ are quite close to the corresponding unweighted estimates based only on the mortality of children to women age 30-34, which represents the standard approach to estimating the $q(5)$ parameter based on indirect estimation techniques (United Nations, 1983). The underfive mortality index can also be used in a regression analysis, which allowed me to estimate under-five mortality rates after controlling for demographic, social, and economic characteristics. The regressions were run using weighted ordinary least squares with the under-five mortality index as the dependent variable and the number of live births to the mother as the weight.

I calculated mortality concentration curves and concentration indices (see Shryock, Siegel, and Associates, 1980) in order to describe and summarize economic inequalities 
in under-five mortality. The concentration curve plots the cumulative proportion of mothers ranked in ascending order by economic status (on the $x$-axis) against the cumulative proportion of mothers ranked by their value of the under-five mortality index (on the $y$-axis). The farther the concentration curve lies above the diagonal, the more that inequalities in mortality favor children from households of higher economic status. The concentration index can be used to compare concentration curves. It is especially useful in situations in which the curves cross and unambiguous comparative assessments of inequality in mortality cannot be made. The concentration index is defined as twice the area between the concentration curve and the diagonal and is negative when the concentration curve lies above the diagonal. I calculated standard errors for the concentration indices using the method of Kakwani, Wagstaff, and van Doorslaer (1997). I used a measure of household wealth based on a principal components analysis of housing characteristics and ownership of consumer durables (see Filmer and Pritchett, 2001) to capture the family's economic status.

\section{Results}

I present my results in three subsections. I begin by describing levels and differentials in under-five mortality according to place of residence, focusing on changes in these differentials over time. Next, I present adjusted and counterfactual measures that control for the effects of a variety of demographic, social, and economic characteristics. Finally, I describe economic inequalities in under-five mortality.

\section{Levels and differentials in under-five mortality}

The estimated under-five mortality rates for São Paulo state were 117.0 for $1970,96.0$ for 1980, and 45.7 for 1991 (see Table 1). Under-five mortality fell by 18 percent between 1970 and 1980 and by 52 percent between 1980 and 1991. Over the entire 21year period, under-five mortality fell by 61 percent.

Table 1 shows that under-five mortality rates were lower in urban areas than in rural areas in all years, although the rural-urban difference was not statistically significant in 1980 in contrast to the other two years. In 1970, the rural and urban under-five mortality rates were 124.7 and 114.4 , respectively; in 1980, they were 97.5 and 95.8; and in 1991, they were 49.8 and 45.2. Looking at mortality rates for different urban areas revealed some interesting findings. In 1970, the under-five mortality rate for the periphery of the São Paulo metro area was nearly as high as it was in rural areas (the difference was not statistically significant); in contrast, rates in the São Paulo metro 
core and in other urban areas were substantially lower. By 1980, the São Paulo metro periphery had significantly higher under-five mortality than other urban areas and rural areas. In 1991, the periphery of metro São Paulo continued to have the highest underfive mortality rates, although the rates were not significantly higher than in rural areas. Among urban areas, towns and cities outside of metro São Paulo consistently had the lowest under-five mortality.

The smaller gap between rural and urban areas in 1980 was likely due to rapid rates of urban population growth between 1970 and 1980 and, in particular, to high rates of migration to urban areas from rural areas of the state and from elsewhere in the country. For the metro São Paulo region, for example, annual population growth rates were 4.5 percent between 1970 and 1980 but only 1.9 percent between 1980 and 1991 (Fundação SEADE, 1993). The periphery of metro São Paulo grew especially rapidly during the 1970s. Table 2 shows that the proportion of mothers age 20-34 who were migrants reached a peak in 1980. In that year, half of all mothers in metro São Paulo had moved to the area from elsewhere in the state or country. This rapid growth strained the ability of local areas to provide adequate levels of infrastructure and public services, resulting in environmental threats to child health, such as poor sanitation, water supply, and access to health care. Table 2 shows that, in particular, improvements in developed sanitation lagged for the periphery of São Paulo between 1970 and 1980. For the São Paulo core and other urban areas, the proportion of households covered by developed sanitation increased by about 50 percent. In contrast, the increase was half as large for the periphery of São Paulo. In addition, migration streams to urban areas of São Paulo were composed to a large extent of disadvantaged families, who may have had a harder time coping in urban areas than in rural areas. For instance, Table 2 shows that the relative gap in mean years of education between the periphery of São Paulo, on one hand, and the core and other urban areas of the state on the other hand, was the widest for 1980. Urban growth during the following decade was much slower, allowing cities to catch up in the provision of public goods.

\section{Adjusted and standardized differentials in under-five mortality by place of residence}

The results presented so far have been of raw differentials in under-five mortality rates. Of considerable interest is the extent to which underlying differences in demographic, social, and economic characteristics shape these results. For instance, low levels of under-five mortality in urban areas may reflect, in part, the survival advantages conferred by higher social and economic status. By controlling for characteristics of the mother and household, I examined rural-urban and intra-urban differentials net of other 
factors. I also examined a series of counterfactual estimates of under-five mortality, which allowed me to decompose differentials into two parts: one associated with differences in group composition (i.e., covariate values) and the other associated with differences in relationships (i.e., covariate effects). The covariates that were included in the analysis are the household possessions-based wealth index, household water supply, household sanitation, mother's education, mother's current age, and mother's migration status.

I started by reexamining rural-urban differentials in under-five mortality. These results are presented in Table 3. Under-five mortality was higher in rural areas than in urban areas for the entire study period. The ratio of rural to urban under-five mortality was 1.09 in 1970, 1.02 in 1980, and 1.10 in 1991. I compared these actual estimates for rural and urban areas for each year with adjusted estimates that hold all other covariates constant at their state-wide means. The adjusted estimates remove the effects of all other covariates, allowing me to examine the extent to which the disadvantaged characteristics of rural families might account for the high levels of under-five mortality in rural areas. I found that the adjusted estimate for urban areas was actually higher than the corresponding estimate for rural areas for each year. In particular, the adjusted rural-to-urban under-five mortality ratio was 0.83 in 1970 (101.0 versus 122.4), 0.75 in 1980 (74.7 versus 99.4), and 0.89 in 1991 (41.3 versus 46.2). This finding indicates that the disadvantaged characteristics of rural families account for more than the observed gap in under-five mortality between rural and urban areas. It suggests that, all other things being equal, rural areas actually provide a more favorable setting for child survival. This may be because rural areas have a less polluted environment, better networks of family and social support, fewer hazards, and less exposure to infectious diseases.

The rural counterfactual provides an estimate of rural under-five mortality if the covariates effects found in urban areas were imposed on rural areas. Under this scenario, rural under-five mortality would have been significantly higher than its observed value in all years, and substantially so in 1970 and 1980. Rather than having an actual under-five mortality of 124.7 in $1970,97.5$ in 1980, and 49.8 in 1991, the prevailing level of mortality in rural areas would have been 152.6 in 1970 (22 percent higher), 125.2 in 1980 (28 percent higher), and 56.0 in 1991 (12 percent higher). This indicates that in all years the same set of characteristics was associated with lower mortality in rural areas than in urban areas. In other words, there were larger deleterious effects for risk factors-and smaller beneficial effects for protective factors-in urban areas compared with rural areas.

Overall, a qualitatively similar set of results emerged from examining the urban counterfactual under-five mortality rates and comparing them to actual rural and urban rates. In summary, rural areas had higher under-five mortality for one main reason, 
which is that the population there was substantially more disadvantaged. However, a similarly disadvantaged urban population would have had even higher under-five mortality because the effects of poor housing conditions, low levels of wealth, and less education were more harmful in urban areas than in rural areas.

Table 4 presents results for intra-urban differentials in under-five mortality, comparing metropolitan São Paulo with other urban areas of the state. In all years, the São Paulo metro area had higher under-five mortality than other urban areas. The rate was 4 percent higher in 1970 (116.8 vs. 111.8), 21 percent higher in 1980 (104.0 vs. 85.6), and 12 percent higher in 1991 (47.9 vs. 42.8). During the period from 1970 to 1980, migration to urban areas of the state peaked, but the destination for most of the migrants was the metropolitan region of São Paulo, particularly the region's periphery (Fundação SEADE, 1993). As explained above, this period of rapid urban growth was likely to have resulted in higher mortality in migrant destinations.

Mothers in metro São Paulo were more disadvantaged on average than those in other urban areas of the state; thus, holding covariate values fixed at mean levels across all urban areas narrowed the under-five mortality gap between these two areas. In 1970, the adjusted gap was small and not significantly significant. In particular, the adjusted under-five mortality rate for metro São Paulo of 114.9 was less than one point higher than the adjusted rate of 114.0 for other urban areas in the state. However, in 1980 and 1991, the gap was narrowed only modestly and remained statistically significant and large: In 1980, adjusted under-five mortality was 16 percent higher in metro São Paulo (102.2) than in other urban areas of the state (87.8), and in 1991, it was six percent higher (46.6 vs. 44.0 ).

Decomposing the differential in under-five mortality between metro São Paulo and other urban areas reveals that in both 1970 and 1991 differences in characteristics accounted for the majority of the under-five mortality gap between metro São Paulo and other urban areas. However, differences in relationships between these two areas accounted for approximately three-quarters of the large differential found for 1980 (Note 6).

Table 5 shows differentials in under-five mortality within the metropolitan region of São Paulo, comparing the core (composed of the municipality of São Paulo) with the periphery (composed of the remainder of the metro region). Under-five mortality was higher in the periphery of metro São Paulo than in the core in all years. The ratio of under-five mortality in the periphery of metro São Paulo compared with the core rose from 1.07 in 1970 (122.9 vs. 114.6), to 1.09 in 1980 (109.6 vs. 100.8), to 1.11 in 1991 (50.9 vs. 45.8). Controlling for covariates revealed that the high under-five mortality rates in the periphery of metro São Paulo reflected in part the relative disadvantage of the population in this area. The adjusted ratio of under-five mortality in the periphery 
of metro São Paulo compared with the core was smaller than the actual ratio, dropping from 1.07 to 1.04 in 1970, from 1.09 to 0.97 in 1980, and from 1.11 to 1.00 in 1991.

A decomposition of the gap in under-five mortality between the core and periphery of metro São Paulo reveals that differences in characteristics between the two areas were likely to have been far more important explanatory factors than differences in covariate effects. Taking the model for the core area as the baseline, I found that for 1970, 51 percent of the 8.3-point gap in under-five mortality between the core (114.6) and the periphery (122.9) was accounted for by differences in characteristics (Note 7). For 1980, differences in characteristics accounted for 100 percent of the gap, whereas for 1991 they accounted for 61 percent (Note 8). If I take the model for the periphery as the baseline, differences in characteristics account for 30 percent of the gap between the core and the periphery of metro São Paulo in 1970 and 100 percent of the gap in both 1980 and 1991. Thus, under-five mortality for the metropolitan region of São Paulo was higher in peripheral areas than in the core because the characteristics of residents of the periphery generally reflected greater levels of disadvantage according to household wealth, mother's education, and household sanitation and water supply.

\section{Inequality in under-five mortality}

I turn finally to presenting information on economic inequality in under-five mortality by area and year. For the state of São Paulo, inequality in under-five mortality by household economic status declined over the study period (see Table 6). The drop occurred between 1970 and 1980, when the concentration index rose from -0.216 to -0.163 . There was a small but statistically significant decrease in the concentration index (indicating higher levels of inequality) between 1980 and 1991, when the concentration index reached -0.175 . The results presented in Table 6 suggest that the rise in inequality between 1980 and 1991 for the state was due to a sharp increase in rural inequality in under-five mortality (because there were declines in inequality for urban areas).

Rural areas had the lowest levels of inequality in under-five mortality according to household economic status in the state in both 1970 and 1980. Although in 1991 the concentration index for rural under-five mortality exceeded the value for urban areas, the difference was not statistically significant. Figure 4 illustrates the convergence in levels of inequality for under-five mortality between rural and urban areas. The top panel shows that in 1970 there was substantially greater economic inequality in mortality in urban areas across the entire range of household wealth. The bottom panel shows that by the end of the study period in 1991, however, it was difficult to distinguish differences in inequality between urban and rural areas in any part of the 
(relative) wealth distribution. Nevertheless, it is clear that between 1980 and 1991, rural inequality increased dramatically to levels well above those found in 1970. Finally, no clear patterns emerged when comparing economic inequalities in mortality across urban areas. However, there were consistent decreases over time in economic inequality in under-five mortality for each urban location.

To assess the robustness of these results and gain additional insights into the trends uncovered, I present information on differentials in under-five mortality by household wealth in urban areas of São Paulo state in Table 7. Two sets of differentials are shown: the ratio of under-five mortality in the first wealth quintile to that in the fifth quintile and the difference in under-five mortality between the top and bottom wealth quintiles. All three indicators (the concentration index and the two differentials) reveal a consistent decrease in levels of inequality in under-five mortality according to household wealth between 1970 and 1991 . The ratio of under-five mortality for the first to fifth quintile of household wealth fell from 3.08 in 1970, to 2.72 in 1980, to 2.22 in 1991. Over this period, the difference in under-five mortality between the first and fifth wealth quintiles shrank relative to the overall level of mortality. In 1970, the difference between the top and bottom wealth quintiles was 116.4, while the overall under-five mortality rate for urban areas was 114.4-indicating that the difference was slightly greater than the overall mortality rate. By 1980, the difference of 91.4 was lower than the overall under-five mortality rate of 95.8 , while by 1991 the difference of 36.5 was only 80 percent of the overall mortality rate of 45.2. These results are consistent with the drop in the concentration index from !0.238 in 1970, to !0.176 in 1980, to !0.163 in 1991.

An examination of under-five mortality rates by wealth quintile reveals that the decline in wealth inequality in under-five mortality was the result of a much larger relative drop in under-five mortality for lower quintiles than for higher quintiles. Specifically, there was a 61-percent decline in under-five mortality for the first quintile between 1970 and 1991, which is one-third larger than the 46 percent decline for the fifth quintile over this period. Overall, and for each group, the magnitude of the mortality declines was much smaller for 1970-1980 than for 1980-1991. For the first wealth quintile, under-five mortality rates fell by 16 percent between 1970 and 1980 but fell by 54 percent between 1980 and 1991 . For the fifth quintile, under-five mortality fell by only 5 percent during the earlier period but fell by 44 percent during the later period. 


\section{Conclusions}

In this paper, I presented trends in rural-urban and intra-urban differentials in under-five mortality in São Paulo state, Brazil, over a 21 year period from 1970 to 1991 . There were major declines in under-five mortality for São Paulo state over this period. These declines were associated with substantial improvements in living conditions, changing urbanization patterns, increases in educational attainment, and other demographic and socioeconomic changes. I found that rural-urban differentials and intra-urban differentials by place were roughly the same at the end of the study period as at the beginning. In contrast, inequality in under-five mortality according to household wealth for urban São Paulo underwent a clear decline over this period, and differences in levels of inequality between rural and urban areas disappeared.

The relatively narrow rural-urban mortality differential has been among the unresolved puzzles in Brazilian mortality patterns (Merrick and Graham, 1979). Our results provide some insights into the reasons for this pattern for under-five mortality. The period from 1970 to 1980 was characterized by rapid urban population growth, due in particular to migration. This growth contributed to poor living conditions in the major destination areas, which included metro São Paulo and, in particular, the periphery of metro São Paulo. Nevertheless, rural families were on average far more disadvantaged and this alone accounted for the higher under-five mortality rates in rural areas than in urban areas. However, children from disadvantaged families were much worse off in urban areas because the deleterious effects of being disadvantaged were much larger in urban areas than they were in rural areas. Intra-urban differences in under-five mortality by place were largely accounted for by the spatial distribution of disadvantaged families. These families were concentrated in the periphery of metro São Paulo, which resulted in this area having the highest under-five mortality rate. Disadvantaged families experienced similar levels of under-five mortality whether they lived in the periphery of São Paulo, the core of the metro area, or in another city or town.

The findings of this study suggest that families on the socioeconomic margin and geographic periphery suffer the worst rates of child mortality. From a policy perspective, these results suggest that mortality differentials between areas could be reduced by improving living conditions, education levels, and economic well-being among the disadvantaged. These lessons may well extend to other areas in Brazil and elsewhere in the developing world that are currently experiencing rapid rates of urbanization. The finding that similarly disadvantaged families fare far worse in urban areas than in rural areas suggests that life in an urban area provides distinct challenges for families trying to promote the health of their children. These may be the 
consequence of factors such as air pollution that are not easily overcome by the types of policies identified above.

From a research perspective, this study has shown the value of using census data and indirect estimate techniques based on individual-level data for examining trends and differentials in child mortality in the developing world. Compared with survey data, which are much more commonly used in studies on this topic, census data have the important strength of considerably larger sample sizes that allow much more statistical precision in tracking changes over time. On the other hand, survey data are often designed to be highly comparable across countries and provide information on child health status in addition to measures of child mortality. Nevertheless, in a number of settings, such as the United States (see Preston and Haines, 1991) and Brazil, census data are unique in their ability to uncover historical trends in mortality inequalities.

\section{Acknowledgements}

I gratefully acknowledge research assistance from Gabriela Lopez and Stephanie Williamson and financial support from the National Institutes of Health through grants HD36695 and HD38556. This paper was prepared for the IUSSP Seminar on Determinants of Diverging Trends in Mortality, Rostock, Germany, June 2002. 


\section{Notes}

1. For information on overall trends see Stolnitz (1965); Gwatkin (1980); Hill and Pebley (1989); and Ahmad, Lopez, and Inoue (2000).

2. Among the recent studies for Brazil that have examined spatial variation in infant or child mortality within urban areas or regions are Akerman, Campanario, and Maia (1996); Akerman et al. (1994); Andrade and Szwarcwald (2001); Campos, Carvalho, and Barcellos (2000); Cavenaghi and Kerber (1996); Costa et al. (2001); da Silva, Paim, and Costa (1999); Terra de Souza et al. (1999 and 2001); Goldani et al. (2001); Leal and Szwarcwald (1997); Morais Neto et al. (2001); Paes-Sousa (2002); Paim and Costa (1993); Shimakura et al. (2001); and Szwarcwald et al. (1999 and 2000). All of these studies were ecological or cross-sectional and most were both. The lack of controls for individual level characteristics is an important shortcoming when trying to uncover the factors that underlie spatial differentials and variation in mortality.

3. Duration since first marriage is often used instead of mother's age, but this information is not available from the Brazilian censuses. However, women of higher socioeconomic status marry or enter into a union later than women of lower socioeconomic status and hence, among mothers of any particular age, children from higher socioeconomic groups would have been exposed to mortality for a shorter period than children from lower socioeconomic groups. Consequently, differences in mortality and fertility would be confounded in comparisons across socioeconomic groups and, in particular, the apparent survival advantage of higher socioeconomic status would be overstated. I adjusted for these important socioeconomic differences by accounting for fertility differences by mother's education level when calculating the child mortality index. I stratified mothers according to whether or not they completed elementary school, since this occurred well before the start of childbearing.

4. Although mother's age is measured and can be included in the analysis, it is confounded with children's exposure.

5. Henceforth, I refer to $q(5) \times 1,000$ as the under-five mortality rate or simply "under-five mortality."

6. In 1970, the under-five mortality differential between metro São Paulo and other urban areas was $116.8-111.8=5.0$. Based on the metro São Paulo counterfactual value of 117.1 (which estimates the under-five mortality rate for São Paulo when imposing relationships found for other urban areas), the entire gap was accounted for by differences in characteristics between the two areas $(117.1-111.8=5.3)$ 
because the effect of differences in coefficients $(116.8-117.1=-0.3)$ actually worked in the opposite direction. Based on the counterfactual value of 114.1 for other urban areas, differences in characteristics $(116.8-114.1=2.7)$ accounted for 55 percent of the gap, whereas differences in relationships $(114.1-111.8=2.3)$ accounted for the remaining 45 percent.

In 1980, the under-five mortality differential between metro São Paulo and other urban areas was $104.0-85.6=18.4$. Based on the metro São Paulo counterfactual value of 90.3 , only 26 percent of the gap $(90.3-85.6=4.7)$ was accounted for by differences in characteristics between the two areas. Based on the other urban areas counterfactual of 100.5, 19 percent of the gap $(104.0-100.5=$ 3.5) was accounted for by differences in characteristics.

Finally, in 1991, there was a differential of $47.9-42.8=5.1$ between metro São Paulo and other urban areas. Between 40 percent (based on the other urban areas counterfactual of 45.8) and 60 percent (based on the São Paulo counterfactual of 45.9) of the gap was accounted for by differences in characteristics between the two areas.

7. Taking the model for the core area as the baseline, the proportion accounted for by differences in characteristics is equal to the predicted values for the periphery minus the predicted value for the core. The predicted under-five mortality for the periphery in 1970, based on average periphery characteristics, was 118.8. The predicted under-five mortality for the core is the actual mortality rate of 114.6 because the model was estimated on these data. Thus, differences in characteristics account for $(118.8-114.6)=4.2$, which is 51 percent of the total gap of 122.9 $114.6=8.3$ points.

8. In 1980, the actual core and periphery under-five mortality rates were 100.8 and 109.6, respectively. The predicted periphery rate based on the model for the core was 112.9. Differences in characteristics thus accounted for (112.9 - 100.8) / $(109.6-100.8)=12.1 / 8.8$, which represents more than 100 percent of the gap. In 1991, the actual and predicted rates for the periphery were 50.9 and 48.9, respectively. Given the actual core rate of 45.8 , differences in characteristics accounted for $(48.9-45.8) /(50.9-45.8)=3.1 / 5.1=0.61$ or 61 percent of the gap. 


\section{References}

Abranches, Sergio. 1995. "Crise e Mudança.” International Labor Office, Geneva.

Adetunji, J.A. 1994. "Infant mortality in Nigeria: effects of place of birth, mother's education and region of residence," Journal of Biosocial Science 26: 469-477.

Ahmad, Omar B., Alan D. Lopez, and Mie Inoue. 2000. "The decline in child mortality: A reappraisal," Bulletin of the World Health Organization 78: 1175-1191.

Akerman, Marco, Paulo Campanario, and Paulo Borlina Maia. 1996. "Saúde e meio ambiente: Análise de diferenciais intra-urbanos, Município de São Paulo, Brasil," Revista Saúde Pública 30: 372-382.

Akerman, Marco, Carolyn Stephens, Paulo Campanario, and Paulo Borlina Maia. 1994. "Saúde e meio ambiente: Uma análise de diferenciais intra-urbanos enfocando o município de São Paulo, Brasil," Revista Saúde Pública 28(4): 320-325.

Andrade, C.L.T., and C.L. Szwarcwald. 2001. "Análise espacial da mortalidade neonatal precoce no Município do Rio de Janeiro, 1995-1996," Caderno de Saúde Pública 17: 1199-1210.

Behm, H., et al. 1976. La mortalidad en los primeros años de vida en países de la América Latina. San José: CELADE.

Behrman, J.R., and A.B. Deolalikar. 1991. "The poor and the social sectors during a period of macroeconomic adjustment: Empirical evidence for Jamaica," World Bank Economic Review 5: 291-314.

Brass, W. et al. 1968. The demography of tropical Africa. Princeton, NJ: Princeton University Press.

Brockerhoff, M. 1990. "Rural-to-urban migration and child survival in Senegal," Demography 27: 601-616.

Brockerhoff, M. 1994. "The impact of rural-urban migration on child survival," Health Transition Review 4: 127-149.

Brockerhoff, M. 1995. "Child survival in big cities: the disadvantages of migrants," Social Science and Medicine 40: 1371-1383.

Campos T.P., M.S. Carvalho, and C.C. Barcellos. 2000. "Mortalidade infantil no Rio de Janeiro, Brasil: áreas de risco e trajetória dos pacientes atfi os serviços de saúde," Revista Panamericana de Salud Pública/Pan American Journal of Public Health 8: 164-171. 
Carvalho, José Alberto M., and Charles H. Wood. 1978. "Mortality, income distribution, and rural-urban residence in Brazil," Population and Development Review 4: 405-420.

Cavenaghi, Suzana, and Lisa Kerber. 1996. "A ecologia da morte: A mortalidade infantil por causas de morte em São Paulo, 1992," in Anais do X Encontro Nacional de Estudos Populacionais, Vol. 4, pp. 2283-2316. Belo Horizonte: ABEP.

Costa, M.C, P.A. Azi, J.S. Paim, and L.M. da Silva. 2001. "Mortalidade infantil e condições de vida: a reprodução das desigualdades sociais em saúde na década de 90," Caderno de Saúde Pública 17: 555-567.

Costa, N.R., and C.M.R. Duarte. 1989. "Notas para avaliação de políticas sociais: A tendência da mortalitdade infantil nas últimas decadas," Dados 32: 241-255.

da Silva, L.M., J.S. Paim, and M.C.N. Costa. 1999 "Desigualdades na mortalidade, espaço e estratos sociais," Revista Saúde Pública 33: 187-197.

Defo, B.K. 1996. "Areal and socioeconomic differentials in infant and child mortality in Cameroon," Social Science and Medicine 42: 399-420.

Evans, P. 1978. Dependent development: The alliance of multinational, state and local capital in Brazil. Princeton, NJ: Princeton University Press.

Filmer, Deon, and Lant H. Pritchett. 2001. "Estimating wealth effects without expenditure data - or tears: An application to educational enrollments in states of India," Demography 38: 115-132.

Fundação SEADE. 1993. O novo retrato de São Paulo: Avaliação dos primeiros resultados do censo demográfico de 1991. Second edition. São Paulo: Fundação SEADE.

Goldani, A.M. 1983. Análise demográfica regional: Grande São Paulo. São Paulo: SEADE.

Goldani M.Z., M.A. Barbieri, H. Bettiol, M.R. Barbieri, A. Tomkins. 2001. "Mortalidade infantil e nível socioeconômico em uma cidade brasileira," Revista Saúde Pública 35: 256-261.

Gwatkin, Davidson R. 1980. "Indications of change in developing country mortality trends: The end of an era?" Population and Development Review 6: 615-644.

Harpham, Trudy, and Marcel Tanner. 1995. Urban health in developing countries: Progress and prospects. London: Earthscan. 
Hill, Kenneth, and Anne R. Pebley. 1989. "Child mortality in the developing world," Population and Development Review 15: 657-687.

Kakwani, Nanak, Adam Wagstaff, and Eddy van Doorslaer. 1997. "Socioeconomic inequalities in health: Measurement, computation, and statistical inference," Journal of Econometrics 77: 87-103.

Leal, M.C., and C.L. Szwarcwald. 1997. "Características da mortalidade neonatal no estado do Rio de Janeiro na década de 80: Uma visão espaço-temporal," Revista Saúde Pública 31: 457-465.

Leser, W. 1974. "Crescimento da população e nível de saúde na cidade de São Paulo," Problemas Brasileiros 16: 17-36.

Macedo, R. 1984. "Brazilian children and the economic crisis: Evidence from São Paulo," World Development 12: 203-221.

Martine, G. 1996. "Brazil's fertility decline, 1965-95: A fresh look at key factors," Population and Development Review 22: 47-75.

Merrick, T.W. 1985. "The effect of piped water on early childhood mortality in urban Brazil, 1970 to 1976," Demography 22: 1-23.

Merrick, Thomas W., and Douglas H. Graham. 1979. Population and economic development in Brazil: 1800 to the present. Baltimore, MD: Johns Hopkins University Press.

Monteiro, C.A., and M.H.A. Benicio. 1989. "Determinants of infant mortality trends in developing countries: Some evidence from São Paulo city," Transactions of the Royal Society of Tropical Medicine and Hygiene 83: 5-9.

Monteiro, C.A., H.P. Pino Zuniga, M.H.A. Benicio, and C.G. Victora. 1989. "Better prospects for child survival," World Health Forum 10: 222-227.

Morais Neto, O.L., M.B.A. Barros, C.M.T. Martelli, S.A. Silva, S.M. Cavenaghi, and J.B. Siqueira. 2001. "Diferenças no padrão de ocorrência da mortalidade neonatal e pós-neonatal no Município de Goiânia, Brasil, 1992-1996: Análise espacial para identificação das áreas de risco," Cadernos de Saúde Pública 17: $1241-1250$.

National Research Council. 1993. Population dynamics of sub-Saharan Africa: Demographic effects of economic reversals in sub-Saharan Africa, Vol. 5. Washington, DC: National Academy of Sciences. 
Paes-Sousa, R. 2002. "Diferenciais intra-urbanos de mortalidade em Belo Horizonte, Minas Gerais, Brasil, 1994: Revisitando o debate sobre transições demográfica e epidemiological," Cadernos de Saúde Pública 18: 1411-1421.

Paim, J.S., and M.C. Costa. 1993. "Decline and unevenness of infant mortality in Salvador, Brazil, 1980-1988," Bulletin of the Pan American Health Organization 27: 1-14.

Palloni, A., K. Hill, and G.P. Aguirre. 1996. "Economic swings and demographic changes in the history of Latin America," Population Studies 50: 105-132.

Preston, Samuel H., and Michael R. Haines. 1991. Fatal years: Child mortality in late nineteenth-century America. Princeton, NJ: Princeton University Press.

Puffer, R.R., and C.V. Serrano. 1973. Patterns of mortality in childhood, Scientific Publication No. 262. Washington, DC: PAHO.

Rios Neto, E.L.G., and M.R. Moreira. 1994. "Crise econômica e seus impactos na mortalidade infantil: Um estudo comparativo das diferenças sócio-econômicas regionais," in Anais do IX Encontro Nacional de Estudos Populacionais, Vol. 1, pp. 99-118. Belo Horizonte: ABEP.

Sastry, Narayan. 1997. "What explains rural-urban differentials in child mortality in Brazil?," Social Science and Medicine 44: 989-1002.

Sawyer, D.O. 1981. "Effects of industrialization and urbanization on mortality in developing countries: The case of Brazil," International Population Conference, Manila 1981. Liège: IUSSP.

Sawyer, D.O., R. Fernández-Castilla, and R.M. Monte-Mor. 1987. "The impact of urbanization and industrialization on mortality in Brazil," World Health Statistics Quarterly 40: 84-95.

Shimakura, S.E., M.S. Carvalho, D.R.G.C. Aerts, and R. Flores. 2001. "Spatial risk distribution: modeling infant mortality in Porto Alegre, Rio Grande do Sul State, Brazil," Caderno de Saúde Pública 17: 1251-1261.

Shryock, Henry S., Jacob S. Siegel, and Associates. 1980. The methods and materials of demography. Washington, DC: U.S. Government Printing Office.

Simões, C.C., and L.A.P. Oliveira. 1997. "A saúde infantil no Brasil nos anos 90," manuscript, IBGE, Rio de Janeiro.

Stolnitz, G.J. 1965. "Recent mortality trends in Latin America, Asia, and Africa: Review and reinterpretation," Population Studies 19: 117-138. 
Sullivan, J.M. 1972. "Models for the estimation of the probability of dying between birth and exact ages of early childhood," Population Studies 26: 79-98.

Szwarcwald, C.L., F.I. Bastos, C. Barcellos, M.F. Pina, and M.A.P. Esteves. 2000. "Health conditions and residential concentration of poverty: A study in Rio de Janeiro, Brazil," Journal of Epidemiology and Community Health 54: 530-536.

Szwarcwald, C.L., F.I. Bastos, M.A.P. Esteves, C.L.T. Andrade, M.S. Paez, E.V. Medici, and M. Derrico. 1999. "Desigualdade de renda e situação de saúde: O caso do Rio de Janeiro," Caderno Saúde Pública 15: 15-28.

Terra de Souza, A.C., E. Cufino, K.E. Peterson, J. Gardner, M.I. Vasconcelos do Amaral, and A. Ascherio. 1999. "Variations in infant mortality rates among municipalities in the state of Ceara, Northeast Brazil: an ecological analysis," International Journal of Epidemiology 28: 267-275.

Terra de Souza, A.C., K.E. Peterson, E. Cufino, M.I. do Amaral, and J. Gardner. 2001. "Underlying and proximate determinants of diarrhoea-specific infant mortality rates among municipalities in the state of Ceara, north-east Brazil: an ecological study," Journal of Biosocial Science 33: 227-244.

Thomas, Vinod. 1987. "Evaluating pollution control: The case of São Paulo," in George S. Tolley and Vinod Thomas (eds.), The economics of urbanization and urban policies in developing countries. Washington, DC: World Bank.

Timaeus, Ian, and Louisiana Lush. 1995. "Intra-urban differentials in child health," Health Transition Review 5: 163-190.

Trussell, J. 1975. "A re-estimation of the multiplying factors for the Brass technique for determining childhood survivorship rates," Population Studies 29: 97-108.

Trussell, James, and Samuel Preston. 1982. "Estimating the covariates of childhood mortality from retrospective reports of mothers," Health Policy and Education 3: $1-36$.

United Nations. 1983. Indirect techniques for demographic estimation. Manual X. New York: United Nations.

Victora, C.G., M.T. Olinto, F.C. Barros, and L.C. Nobre. 1996. "Falling diarrhoea mortality in Northeast Brazil: Did ORT play a role?" Health Policy and Planning 11: 132-141.

Wood, C.H. 1982. "The political economy of infant mortality in São Paulo, Brazil," International Journal of Health Services 12: 215-229. 
Wood, C.H., and J.A.M. Carvalho. 1988. The demography of inequality in Brazil. New York: Cambridge University Press.

Yunes, J. 1981. "Evolution of infant mortality and proportional infant mortality in Brazil," WHO Statistical Quarterly 34: 200-219.

Zúñiga, H.P.P., and C.A. Monteiro. 1995. "Uma nova hipótese para a ascensão da mortalidade infantil da cidade de São Paulo nos anos 60," in C.A. Monteiro (ed.), Velhos e novos males da saúde no Brasil. São Paulo: HUCITEC. 
Demographic Research - Special Collection 2: Article 14

-- Determinants of Diverging Trends in Mortality --

\section{Tables \& Figures}

Table 1: $\quad$ Under-five mortality by area for São Paulo state by year

\begin{tabular}{|c|c|c|c|}
\hline Area & \multicolumn{2}{|c|}{ Under-five mortality } & \multirow[t]{2}{*}{$\begin{array}{c}\text { Sample size } \\
\text { (mothers) }\end{array}$} \\
\hline & & & \\
\hline Total & 117.0 & $(0.36)$ & 297,729 \\
\hline Urban & 114.4 & $(0.41)$ & 233,252 \\
\hline São Paulo metropolitan area & 116.8 & $(0.57)$ & 124,609 \\
\hline São Paulo metro core & 114.6 & $(0.61)$ & 92,781 \\
\hline São Paulo metro periphery & 122.9 & $(1.04)$ & 31,828 \\
\hline Other urban areas & 111.9 & $(0.56)$ & 108,643 \\
\hline \multirow[t]{2}{*}{ Rural } & 124.7 & $(0.78)$ & 64,477 \\
\hline & \multicolumn{3}{|c|}{1980} \\
\hline Total & 96.0 & $(0.31)$ & 527,927 \\
\hline Urban & 95.8 & $(0.33)$ & 465,877 \\
\hline São Paulo metropolitan area & 104.0 & $(0.45)$ & 262,483 \\
\hline São Paulo metro core & 100.8 & $(0.57)$ & 172,621 \\
\hline São Paulo metro periphery & 109.6 & $(0.78)$ & 89,862 \\
\hline Other urban areas & 85.6 & $(0.47)$ & 203,394 \\
\hline \multirow[t]{2}{*}{ Rural } & 97.5 & $(0.89)$ & 62,050 \\
\hline & \multicolumn{3}{|c|}{1991} \\
\hline Total & 45.7 & $(0.21)$ & 406,976 \\
\hline Urban & 45.2 & $(0.22)$ & 371,020 \\
\hline São Paulo metropolitan area & 47.9 & $(0.31)$ & 175,262 \\
\hline São Paulo metro core & 45.8 & $(0.43)$ & 103,137 \\
\hline São Paulo metro periphery & 50.9 & $(0.52)$ & 72,125 \\
\hline Other urban areas & 42.8 & $(0.29)$ & 195,758 \\
\hline Rural & 49.8 & $(0.72)$ & 35,956 \\
\hline
\end{tabular}

Source: Author's calculations based on microdata data for São Paulo state from Brazilian censuses of 1970, 1980, and 1991.

Notes: Standard errors in parentheses.

The under-five mortality rate is equal to $q(5) \times 1,000$, where $q(5)$ is an estimate of the life table probability of a child dying before age 5 . The estimate of $q(5)$ is calculated from the ratio of observed to expected child deaths among women age 20-34 with one or more births and a model life table, using indirect estimation techniques. See text for details. 
Demographic Research - Special Collection 2: Article 14

-- Determinants of Diverging Trends in Mortality --

Table 2: $\quad H o u s e h o l d$ and mother characteristics by area for São Paulo state by year

\begin{tabular}{|c|c|c|c|c|c|c|}
\hline \multirow[b]{2}{*}{ Variable } & \multicolumn{6}{|c|}{ Area } \\
\hline & Rural & Urban & $\begin{array}{c}\text { São Paulo } \\
\text { metro }\end{array}$ & Other urban & $\begin{array}{l}\text { São Paulo } \\
\text { core }\end{array}$ & $\begin{array}{l}\text { São Paulo } \\
\text { periphery }\end{array}$ \\
\hline & \multicolumn{6}{|c|}{1970} \\
\hline \multicolumn{7}{|l|}{ Water supply } \\
\hline Piped/well internal & $17 \%$ & $62 \%$ & $63 \%$ & $62 \%$ & $65 \%$ & $58 \%$ \\
\hline Other & $83 \%$ & $38 \%$ & $37 \%$ & $38 \%$ & $35 \%$ & $42 \%$ \\
\hline \multicolumn{7}{|l|}{ Sanitation } \\
\hline Developed & $7 \%$ & $52 \%$ & $50 \%$ & $53 \%$ & $51 \%$ & $48 \%$ \\
\hline Other & $93 \%$ & $48 \%$ & $50 \%$ & $47 \%$ & $49 \%$ & $52 \%$ \\
\hline Mother's education (years) & 1.62 & 3.47 & 3.54 & 3.39 & 3.65 & 3.22 \\
\hline Non-migrant & $78 \%$ & $68 \%$ & $59 \%$ & $78 \%$ & $57 \%$ & $64 \%$ \\
\hline & \multicolumn{6}{|c|}{1980} \\
\hline \multicolumn{7}{|l|}{ Water supply } \\
\hline Piped/well internal & $46 \%$ & $84 \%$ & $84 \%$ & $82 \%$ & $87 \%$ & $78 \%$ \\
\hline Other & $54 \%$ & $16 \%$ & $16 \%$ & $18 \%$ & $13 \%$ & $22 \%$ \\
\hline \multicolumn{7}{|l|}{ Sanitation } \\
\hline Developed & $25 \%$ & $74 \%$ & $71 \%$ & $78 \%$ & $76 \%$ & $60 \%$ \\
\hline Other & $75 \%$ & $26 \%$ & $29 \%$ & $22 \%$ & $14 \%$ & $40 \%$ \\
\hline Mother's education (years) & 3.01 & 5.35 & 5.39 & 5.30 & 5.70 & 4.80 \\
\hline \multirow[t]{2}{*}{ Non-migrant } & $74 \%$ & $61 \%$ & $50 \%$ & $77 \%$ & $49 \%$ & $50 \%$ \\
\hline & \multicolumn{6}{|c|}{1991} \\
\hline \multicolumn{7}{|l|}{ Water supply } \\
\hline Piped/well internal & $83 \%$ & $96 \%$ & $96 \%$ & $95 \%$ & $98 \%$ & $95 \%$ \\
\hline Other & $17 \%$ & $4 \%$ & $4 \%$ & $5 \%$ & $2 \%$ & $5 \%$ \\
\hline \multicolumn{7}{|l|}{ Sanitation } \\
\hline Developed & $32 \%$ & $84 \%$ & $82 \%$ & $86 \%$ & $89 \%$ & $74 \%$ \\
\hline Other & $68 \%$ & $16 \%$ & $18 \%$ & $14 \%$ & $11 \%$ & $26 \%$ \\
\hline Mother's education (years) & 4.53 & 6.66 & 6.82 & 6.51 & 7.21 & 6.27 \\
\hline Non-migrant & $76 \%$ & $67 \%$ & $55 \%$ & $77 \%$ & $56 \%$ & $52 \%$ \\
\hline
\end{tabular}

Source: $\quad$ Author's calculations based on microdata data for São Paulo state from Brazilian censuses of 1970, 1980 , and 1991. 
Demographic Research - Special Collection 2: Article 14

-- Determinants of Diverging Trends in Mortality --

Table 3: $\quad$ Adjusted and counterfactual levels of under-five mortality for rural and urban areas of São Paulo state by year

\begin{tabular}{|c|c|c|c|c|c|}
\hline \multirow[b]{2}{*}{ Measure } & \multirow{2}{*}{$\begin{array}{l}\text { Covariate } \\
\text { values }\end{array}$} & \multirow{2}{*}{$\begin{array}{l}\text { Coefficient } \\
\text { effects }\end{array}$} & \multicolumn{2}{|c|}{ Under-five mortality } & \multirow[b]{2}{*}{ Rural / Urban } \\
\hline & & & Rural & Urban & \\
\hline & & & & 1970 & \\
\hline Actual estimates & Own & Own & $124.7(0.78)$ & $114.4(0.41)$ & 1.09 \\
\hline Adjusted for all covariates & State means & State-wide & $101.0(0.84)$ & $122.4(0.44)$ & 0.83 \\
\hline Rural counterfactual & Own & Urban & $152.6(0.91)$ & $-\quad-$ & - \\
\hline \multirow[t]{2}{*}{ Urban counterfactual } & Own & Rural & $-\quad-$ & $108.7(2.14)$ & - \\
\hline & & & & 1980 & \\
\hline Actual estimates & Own & Own & $97.5(0.89)$ & $95.8(0.33)$ & 1.02 \\
\hline Adjusted for all covariates & State means & State-wide & 74.7 (1.06) & $99.4(0.35)$ & 0.75 \\
\hline Rural counterfactual & Own & Urban & $125.2(0.90)$ & $-\quad-$ & - \\
\hline \multirow[t]{2}{*}{ Urban counterfactual } & Own & Rural & $-\quad-$ & $92.7(2.84)$ & - \\
\hline & & & & 1991 & \\
\hline Actual estimates & Own & Own & $49.8 \quad(0.72)$ & $45.2(0.22)$ & 1.10 \\
\hline Adjusted for all covariates & State means & State-wide & $41.3(0.95)$ & $46.2(0.23)$ & 0.89 \\
\hline Rural counterfactual & Own & Urban & $56.0(0.96)$ & $-\quad-$ & - \\
\hline Urban counterfactual & Own & Rural & $-\quad-$ & $43.6(2.05)$ & - \\
\hline
\end{tabular}

Source: Author's calculations based on microdata data for São Paulo state from Brazilian censuses of 1970, 1980 , and 1991.

Notes: Standard errors in parentheses.

See notes to Table 1 for information about the measure of under-five mortality.

Adjusted estimates control for covariates and set each covariate to its mean across all areas. Counterfactual estimates are predictions based on own-characteristics but coefficient estimates from a model estimated for the other area.

Covariates used for the adjustments and counterfactuals include a household possessions-based wealth index, household water supply, household sanitation, woman's education, woman's current age, and woman's interstate migration status.

Covariates were incorporated through the use of a linear regression model. 
Demographic Research - Special Collection 2: Article 14

-- Determinants of Diverging Trends in Mortality --

Table 4: $\quad$ Adjusted and counterfactual levels of under-five mortality for metropolitan São Paulo and for other urban areas of São Paulo state by year

\begin{tabular}{|c|c|c|c|c|c|c|c|}
\hline \multirow[b]{2}{*}{ Measure } & \multirow[b]{2}{*}{$\begin{array}{l}\text { Covariate } \\
\text { values }\end{array}$} & \multicolumn{6}{|c|}{ Under-five mortality } \\
\hline & & $\begin{array}{l}\text { Coefficient } \\
\text { effects }\end{array}$ & \multicolumn{2}{|c|}{$\begin{array}{l}\text { Metropolitan } \\
\text { São Paulo }\end{array}$} & \multicolumn{2}{|c|}{$\begin{array}{l}\text { Other urban } \\
\text { areas }\end{array}$} & $\begin{array}{l}\text { Metro São } \\
\text { Paulo / Other } \\
\text { urban areas }\end{array}$ \\
\hline Actual estimates & Own & Own & 116.8 & $(0.57)$ & 111.8 & $(0.56)$ & 1.04 \\
\hline Adjusted for all covariates & Urban means & All-urban & 114.9 & $(0.61)$ & 114.0 & $(0.63)$ & 1.01 \\
\hline $\begin{array}{l}\text { Metro São Paulo } \\
\text { counterfactual }\end{array}$ & Own & Other urban & 117.1 & $(0.93)$ & - & - & - \\
\hline Other urban counterfactual & Own & Metro São Paulo & - & - & 114.1 & $(1.02)$ & - \\
\hline & & & \multicolumn{5}{|c|}{1980} \\
\hline Actual estimates & Own & Own & 104.0 & $(0.45)$ & 85.6 & $(0.47)$ & 1.21 \\
\hline Adjusted for all covariates & Urban means & All-urban & 102.2 & $(0.46)$ & 87.8 & $(0.51)$ & 1.16 \\
\hline $\begin{array}{l}\text { Metro São Paulo } \\
\text { counterfactual }\end{array}$ & Own & Other urban & 90.3 & $(0.61)$ & - & - & - \\
\hline Other urban counterfactual & Own & Metro São Paulo & - & - & 100.5 & $(0.59)$ & - \\
\hline & & & \multicolumn{5}{|c|}{1991} \\
\hline Actual estimates & Own & Own & 47.9 & $(0.31)$ & 42.8 & $(0.29)$ & 1.12 \\
\hline Adjusted for all covariates & Urban means & All-urban & 46.6 & $(0.32)$ & 44.0 & $(0.30)$ & 1.06 \\
\hline $\begin{array}{l}\text { Metro São Paulo } \\
\text { counterfactual }\end{array}$ & Own & Other urban & 45.9 & $(0.35)$ & - & - & - \\
\hline Other urban counterfactual & Own & Metro São Paulo & - & - & 45.8 & $(0.39)$ & - \\
\hline
\end{tabular}

Source: Author's calculations based on microdata data for São Paulo state from Brazilian censuses of 1970, 1980, and 1991.

Notes: Standard errors in parentheses.

See notes to Table 1 for information about the measure of under-five mortality.

Adjusted estimates control for covariates and set each covariate to its mean across all urban areas. Counterfactual estimates are predictions based on own-characteristics but coefficient estimates from a model estimated for the other area. See notes to Table 3 for information on the covariates in the models. 
Demographic Research - Special Collection 2: Article 14

-- Determinants of Diverging Trends in Mortality --

Table 5: $\quad$ Adjusted and counterfactual levels of under-five mortality for the core and periphery of metropolitan São Paulo by year

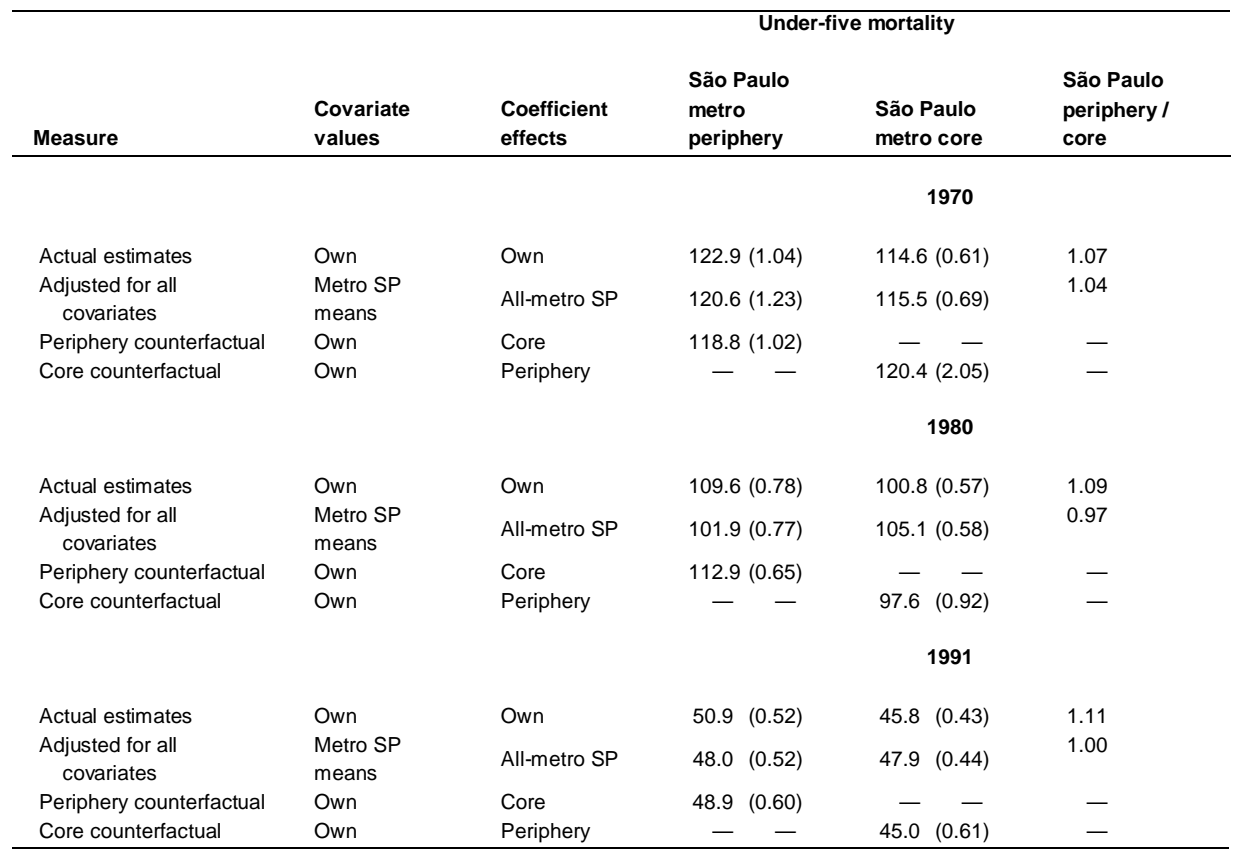

Source: Author's calculations based on microdata data for São Paulo state from Brazilian censuses of 1970, 1980 , and 1991.

Notes: Standard errors in parentheses.

See notes to Table 1 for information about the measure of under-five mortality.

Adjusted estimates control for covariates and set each covariate to its mean across the metropolitan São Paulo region. Counterfactual estimates are predictions based on own-characteristics but coefficient estimates from a model estimated for the other area.

See notes to Table 3 for information on the covariates in the models. 
Demographic Research - Special Collection 2: Article 14

-- Determinants of Diverging Trends in Mortality --

Table 6: $\quad$ Inequality in under-five mortality by area for São Paulo by year

\begin{tabular}{|c|c|c|c|c|c|c|c|}
\hline \multirow[b]{2}{*}{ Area } & & \multicolumn{6}{|c|}{ Concentration index } \\
\hline & & \multicolumn{2}{|c|}{1970} & \multicolumn{2}{|c|}{1980} & \multicolumn{2}{|c|}{1991} \\
\hline Total & & -0.216 & $(0.0023)$ & -0.163 & $(0.0023)$ & -0.175 & $(0.0036)$ \\
\hline & Urban & -0.238 & $(0.0027)$ & -0.176 & $(0.0025)$ & -0.163 & $(0.0038)$ \\
\hline & São Paulo metropolitan area & -0.238 & $(0.0037)$ & -0.172 & (0.0033) & -0.155 & $(0.0055)$ \\
\hline & São Paulo metro core & -0.239 & $(0.0044)$ & -0.167 & $(0.0042)$ & -0.161 & $(0.0076)$ \\
\hline & São Paulo metro periphery & -0.231 & $(0.0069)$ & -0.175 & $(0.0051)$ & -0.137 & $(0.0080)$ \\
\hline & Other urban areas & -0.241 & $(0.0039)$ & -0.179 & $(0.0040)$ & -0.169 & $(0.0054)$ \\
\hline & Rural & -0.120 & $(0.0047)$ & -0.098 & $(0.0064)$ & -0.174 & $(0.0110)$ \\
\hline
\end{tabular}

Source: Author's calculations based on microdata data for São Paulo state from Brazilian censuses of 1970, 1980 , and 1991.

Notes: Standard errors in parentheses.

The concentration index is a measure of economic inequality in under-five mortality constructed using a household possessions-based wealth index. The index of household wealth is the score of a principal components analysis, with components that include the ownership of consumer durables such as a car, radio, refrigerator, and television, and the number of rooms and bedrooms in the dwelling. See text for further details.

Table 7: $\quad$ Levels and inequality of under-five mortality by wealth for urban areas of São Paulo state by year

\begin{tabular}{|c|c|c|c|c|c|c|c|c|c|}
\hline \multirow[b]{2}{*}{ Measure } & \multicolumn{3}{|c|}{1970} & \multicolumn{3}{|c|}{1980} & \multicolumn{3}{|c|}{1991} \\
\hline & \multicolumn{2}{|c|}{$\begin{array}{c}\text { Under-five } \\
\text { mortality }\end{array}$} & \multirow[t]{2}{*}{$\begin{array}{l}\text { Percent } \\
\text { in } \\
\text { category }\end{array}$} & \multicolumn{2}{|c|}{$\begin{array}{c}\text { Under-five } \\
\text { mortality }\end{array}$} & \multirow[t]{2}{*}{$\begin{array}{l}\text { Percent } \\
\text { in } \\
\text { category }\end{array}$} & \multicolumn{2}{|c|}{$\begin{array}{c}\text { Under-five } \\
\text { mortality }\end{array}$} & \multirow[t]{2}{*}{$\begin{array}{l}\text { Percent } \\
\text { in } \\
\text { category }\end{array}$} \\
\hline & & & & & & & & & \\
\hline 1 & 172.4 & $(1.04)$ & $20.3 \%$ & 144.5 & $(0.84)$ & $20.0 \%$ & 66.5 & $(0.58)$ & $20.0 \%$ \\
\hline 2 & 131.3 & $(0.96)$ & $19.8 \%$ & 106.8 & $(0.73)$ & $22.3 \%$ & 47.8 & $(0.51)$ & $20.2 \%$ \\
\hline 3 & 102.7 & $(0.87)$ & $20.1 \%$ & 83.0 & $(0.71)$ & $19.4 \%$ & 42.3 & $(0.47)$ & $20.0 \%$ \\
\hline 4 & 75.2 & $(0.79)$ & $20.5 \%$ & 68.8 & $(0.66)$ & $20.2 \%$ & 35.3 & $(0.44)$ & $19.9 \%$ \\
\hline 5 & 56.0 & $(0.70)$ & $19.3 \%$ & 53.1 & $(0.65)$ & $18.1 \%$ & 30.0 & $(0.42)$ & $19.8 \%$ \\
\hline Total & 114.4 & $(0.41)$ & $100.0 \%$ & 95.8 & $(0.33)$ & $100,0 \%$ & 45.2 & $(0.22)$ & $100.0 \%$ \\
\hline Ratio: $\min$ to $\max$ & 3.08 & & 1.05 & 2.72 & & 1.10 & 2.22 & & 1.01 \\
\hline Max - min & 116.4 & & & 91.4 & & & 36.5 & & \\
\hline $\begin{array}{l}\text { Concentration } \\
\text { Index }\end{array}$ & -0.238 & $(0.0028)$ & & -0.176 & $(0.0025)$ & & -0.163 & $(0.0038)$ & \\
\hline
\end{tabular}

Source: Author's calculations based on microdata data for São Paulo state from Brazilian censuses of 1970, 1980, and 1991.

Notes: Standard errors in parentheses.

See notes to Table 1 for information on the measure of under-five mortality and to Table 6 for information on the concentration index. 
Demographic Research - Special Collection 2: Article 14

-- Determinants of Diverging Trends in Mortality --
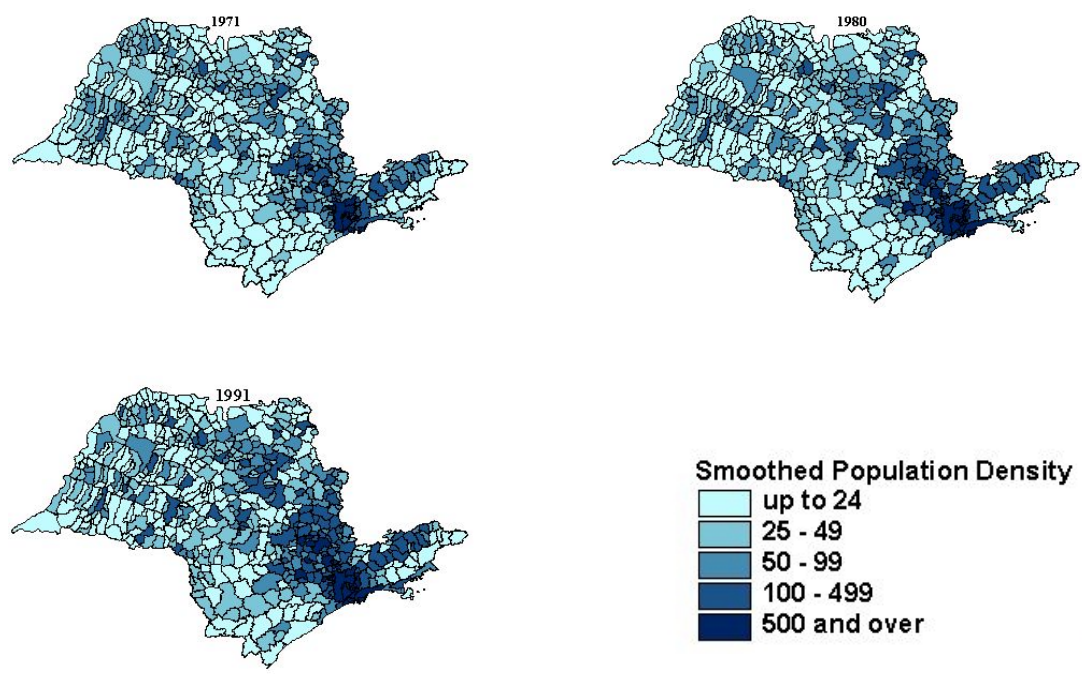

Smoothed Population Density

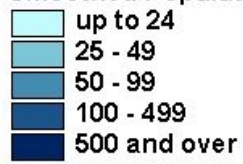

Figure 1: $\quad$ Spatially smoothed municipality estimates of population density, São Paulo, Brazil, 1970-1996

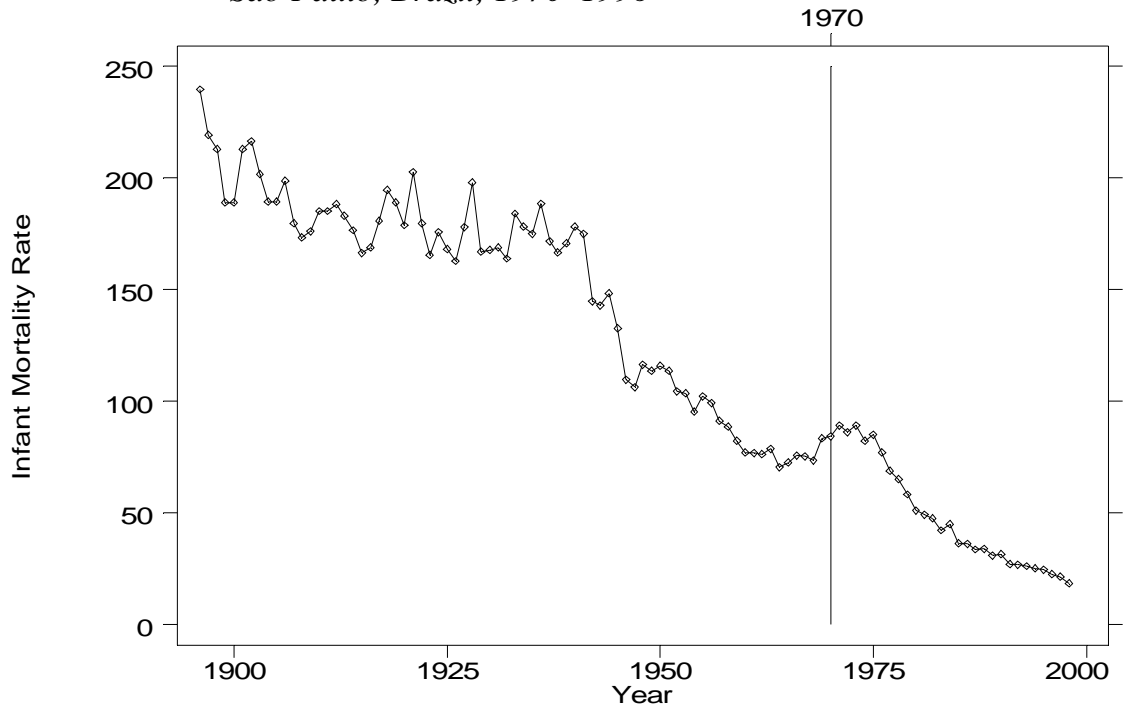

Figure 2: $\quad$ Infant mortality rate for São Paulo state, 1894-1998 
Demographic Research - Special Collection 2: Article 14

-- Determinants of Diverging Trends in Mortality --
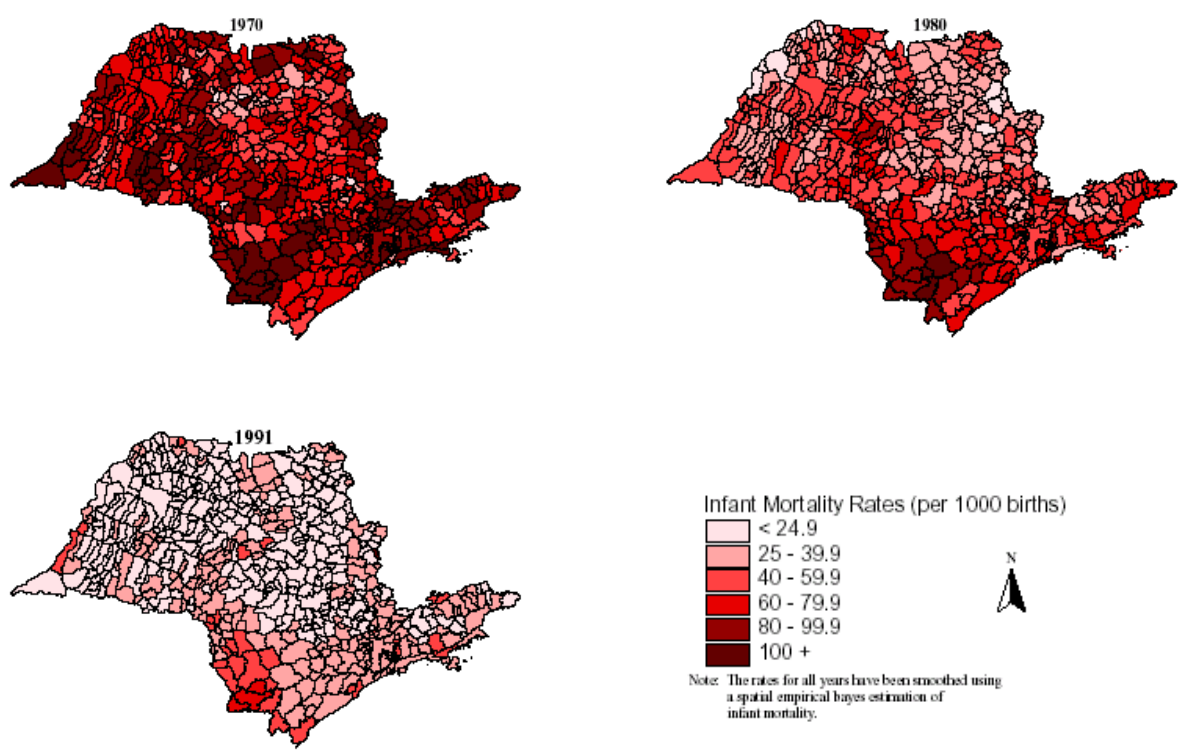

Figure 3: $\quad$ Spatially smoothed municipality estimates of infant mortality rates, São Paulo, Brazil, 1970-1991 
Demographic Research - Special Collection 2: Article 14

-- Determinants of Diverging Trends in Mortality --

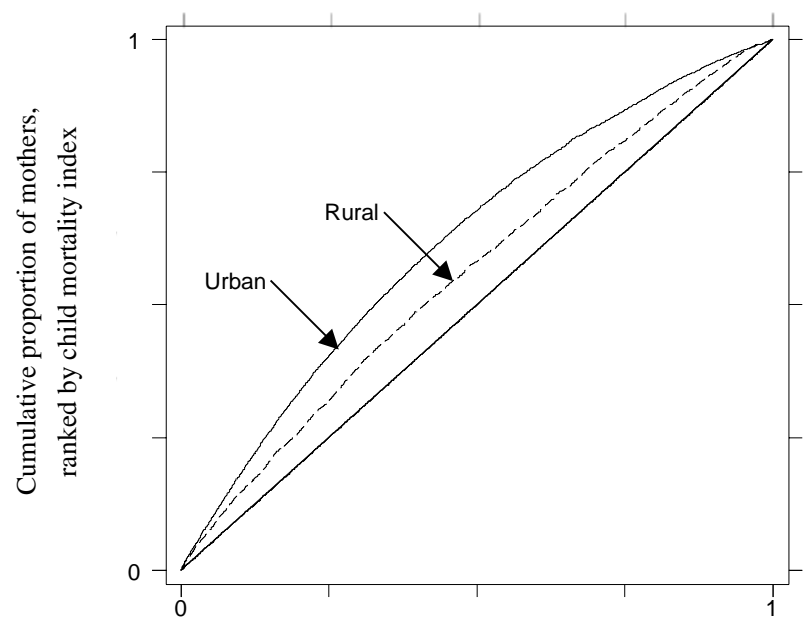

Cumulative proportion of mothers, ranked by household wealth

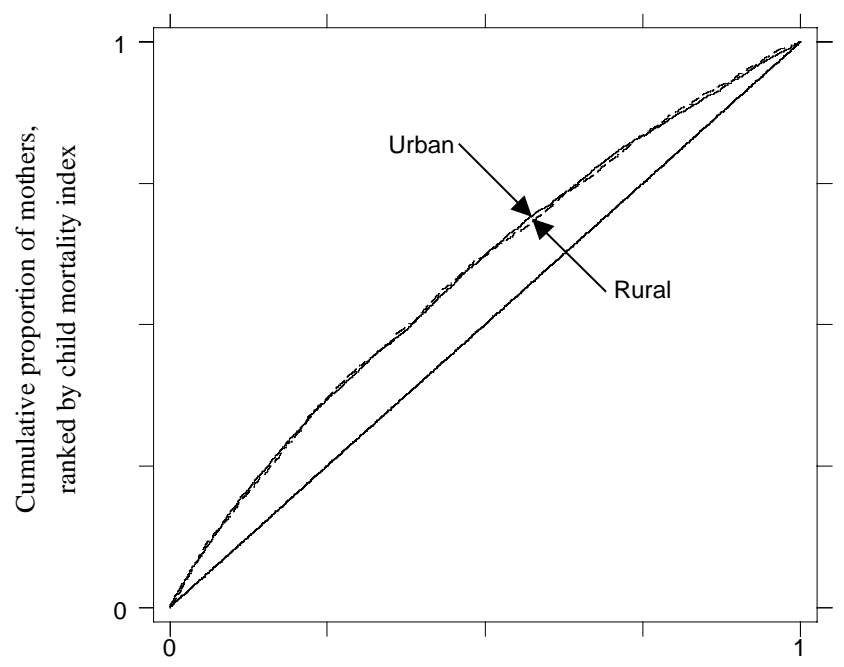

Cumulative proportion of mothers, ranked by household wealth

Figure 4: $\quad$ Concentration curves for under-five mortality by wealth for rural and urban São Paulo state, 1970 (top panel) and 1991 (bottom panel) 